\title{
Studi Fenomenologi: Pengalaman Keluarga Merawat Penderita Pasca Stroke di Kota Jambi Tahun 2019
}

\author{
Kadarwati ${ }^{1}$, Rahmi Ulfa ${ }^{2}$, Elvi Oktarina ${ }^{3}$ \\ ${ }^{1}$ Program Magister Keperawatan Universitas Andalas, Jl. Kampus Limau Manis Padang 25163 Telp.0751-779233 \\ ${ }^{2}$ Dokter Spesialis Saraf Rumah Sakit Umum Daerah Dr. Rasidin, Jl. Air Paku, Gn.Sarik, \\ Kec. Kuranji Kota Padang 25586 Telp 0751-499150 \\ ${ }^{3}$ Dosen Fakultas Keperawatan Universitas Andalas, Jl. Kampus Limau Manis Padang 25163 Telp.0751-779233 \\ Correspondence e-mail: kadarwati11@yahoo.com
}

\begin{abstract}
Abstrak. Stroke berdampak negatif pada keluarga yang memberikan perawatan pada penderita pasca stroke, dampak tersebut disebabkan defisit fungsional yang dialami penderita pasca stroke yang mengakibatkan ketergantungan pada keluarga untuk aktifitas sehari-hari. Tujuan penelitian untuk mengeksplor secara mendalam pengalaman keluarga merawat penderita pasca stroke di kota Jambi tahun 2019. Penelitian ini mengunakan metode kualitatif dengan pendekatan fenomenologi deskriptif. Partisipan dalam penelitian ini berjumlah sembilan orang yang dipilih menggunakan purposive sampling. Data dikumpulkan dengan indepth interview semi terstruktur durasi 60-90 menit. Analisa data mengunakan metode colaizzi. Hasil ditemukan empat tema yaitu: ketergantungan aktifitas sehari-hari pada keluarga, upaya yang dilakukan keluarga memenuhi aktifitas perawatan diri, kendala yang dihadapi pada pemberi asuhan dan harapan keluarga. Kesimpulan: Keluarga mengalami keterbatasan pengetahuan dan keterampilan, kesulitan dalam memenuhi ADL pasien, perubahan kondisi fisik, perubahan istirahat dan tidur, perubahan kondisi psikologis, perubahan aktifitas sosial, dan perubahan ekonomi. Oleh karena itu keluarga perlu mendapatkan edukasi dari dokter, perawat dan anggota tim stroke dimulai sejak pasien masuk rumah sakit dan dievaluasi kembali pada saat pasien akan pulang, mengenai pengetahuan dan keterampilan merawat penderita pasca stroke dirumah.
\end{abstract}

Kata kunci : Pengalaman Keluarga; Merawat; Penderita Stroke.

Abstract. Stroke has a negative impact on families who provide care for post-stroke patients, the effect of which is due to functional deficits experienced by post-stroke sufferers which result in dependence on families for daily activities. The research objective was to explore in depth the experiences of families caring for post-stroke sufferers in Jambi city in 2019. This study used a qualitative method with a descriptive phenomenology approach. Participants in this study amounted to nine people who were selected using purposive sampling. Data is collected by semi-structured interview in duration of 60-90 minutes. Data analysis using the colaizzi method. The results found four themes, namely: dependence on daily activities on the family, family efforts to fulfill self-care activities, constraints faced by caregivers and family expectations. Conclusion: Families experience limited knowledge and skills, difficulties in meeting patients' ADLs, changes in physical conditions, changes in rest and sleep, changes in psychological conditions, changes in social activities, and economic changes. Therefore families need to get education from doctors, nurses and stroke team members starting from the time the patient is admitted to the hospital and re-evaluated when the patient is going home, about the knowledge and skills to treat post-stroke patients at home.

Keywords : Family Experience; Caring for; Stroke Sufferers

\section{PENDAHULUAN}

Stroke adalah gangguan suplai darah ke otak terjadi karena sumbatan atau pecahnya pembuluh darah yang mengakibatkan berkurangnya pasokan oksigen dan nutrisi ke otak, sehingga menyebabkan kerusakan pada jaringan otak (WHO, 2018). Stroke masih menduduki posisi kedua penyebab kematian didunia dari tahun 2000 sampai dengan tahun 2016 dan penyebab utama ketiga kecacatan di dunia (Johnson, Onuma, Owolabi, \& Sachdev, 2016; WHO, 2018). Indonesia menjadi peringkat kedua kematian yang disebabkan stroke sebanyak 193,3 per 100.000 orang/tahun di Asia (Venketasubramanian, Yoon, Pandian, \& Navarro, 2017).

Selain menyebabkan kematian, stroke menyebabkan defisit neurologis berupa defisit motorik, sensorik, defisit verbal, defisit kognitif, defisit emosional dan disfungsi kandung kemih (Smeltzer, Hinkle, Bare, \& Cheever, 2009). Defisit neurologis yang dialami penderita pasca stroke berdampak pada aspek fisik, psikologis, kehidupan sosial dan penurunan kualitas hidup pada penderita stroke (Taştekin, 2015). Gangguan neurologis kronis yang dialami sekitar dua pertiga penderita stroke berdampak pada aktifitas sehari- hari pasien. Gangguan tersebut mengakibatkan sebanyak $24-53 \%$ penderita stroke tergantung pada pengasuh keluarga untuk aktifitas sehari-hari terutama mobilisasi (Hesamzadeh et al., 2016).

Pelaksanaan Program Indonesia Sehat dilakukan dengan pendekatan keluarga (Kemenkes RI, 2017). Keluarga sebagai fokus program tersebut karena menurut teori Friedman, Bowden, \& Jones, (2010) keluarga mempunyai lima fungsi diantaranya fungsi perawatan atau pemeliharaan kesehatan penderita pasca stroke. Selama memberikan perawatan penderita stroke dirumah, keluarga berupaya meningkatkan kemampuan pasien untuk mandiri, meningkatkan percaya diri pasien, meminimalkan kecacatan seringan mungkin, dan mencegah stroke berulang (Kemenkes RI Ditjen Yankes, 2018). Merawat penderita stroke berdampak negatif pada kesejahteraan sosial, emosional, kesehatan, dan keuangan dari Caregiver informal (Gbiri, Olawale, \& Isaac, 2015). Caregiver juga mengalami masalah fisik, berupa sakit kepala $46 \%$, kesulitan tidur $42 \%$, sakit perut $53 \%$, tekanan darah tinggi $31 \%$, kolesterol tinggi $10 \%$, dan masalah psikologis kecemasan/kegelisahan $71 \%$, depresi $50 \%$, 
tugas merawat penderita stroke dilaporkan sebagai penyebab untuk gejala tersebut (Ganapathy et al., 2015)

Penelitian kualitatif mengenai perspektif pengalaman keluarga sebagai caregiver, menemukan keluarga memiliki peran penting dalam menangani ketergantungan ADL pasien stroke, keluarga juga mengalami masalah fisik, psikologis dan sosial dalam memberikan perawatan pasien stroke (Daulay, Setiawan, \& Sitepu, 2014). Tujuan dari penelitian ini adalah mengeksplor pengalaman keluarga merawat penderita pasca stroke di kota Jambi tahun 2019.

\section{METODE PENELITIAN}

Penelitin ini mengunakan metode penelitian kualitatif dengan pendekatan fenomenologi deskriptif, pengumpulan data dilakukan dikota Jambi selama 4 minggu mulai pada tanggal 9 Maret sampai dengan 9 April 2019. Tempat wawancara disesuaikan dengan keinginan partisipan yaitu dirumah partisipan. Partisipan dalam penelitian ini diperoleh dari data rekam medik zal saraf RSUD Raden Mattaher Provinsi Jambi. Partisipan dalam penelitian ini berjumlah 9 orang yang dipilih dengan mengunakan purposive sampling, dengan kriteria yaitu bersedia menjadi partisipan dan berdomisili dijambi, mampu berkomunikasi dengan baik, merawat penderita pasca stroke dengan NIHSS $\geq 8$ dan memberikan perawatan minimal $\geq 1$ bulan, tipe keluarga extended family. Keluarga yang merawat penderita stroke yang mengalami penurunan kesadaran/koma tidak termasuk dalam kriteria penelitian ini. Partisipan dalam penelitian ini sudah mencapai saturasi data, dengan kata lain tidak ada informasi baru yang ditemukan.

Data dikumpulkan dengan indepth interview semi terstruktur dilakukan oleh peneliti sendiri, dengan mengunakan pedoman wawancara dengan durasi 60-90 menit. Pedoman wawancara berisikan sejumlah pertanyaan terbuka yang standar, mengunakan kalimat dan kata-kata yang dengan mudah dimengerti partisipan, yang berfokus pada subjek area yang diteliti.

Pedoman wawancara dibuat untuk memudah peneliti sehingga wawancara terarah dan sesuai dengan penelitian. Selain itu, pedoman wawancara berguna untuk mengingatkan peneliti terhadap subjek area yang diteliti. Pedoman wawancara yang digunakan peneliti sebelumnya dilakukan uji expert yang dikonsultasikan dengan yang ahli, setelah mendapatkan persetujuan, berarti pedoman wawancara tersebut valid dan layak dijadikan pedoman wawancara.

Prosedur pengumpulan data dalam penelitian ini diawali dari surat keterangan lulus uji etik dan surat keterangan izin penelitian dari Fakultas Keperawatan Universitas Andalas Padang. Selanjutnya peneliti melakukan pilot studi pada satu partisipan, setelah hasil wawancara dibuat dalam transkrip yang telah dibuat sesegera mungkin setelah wawancara, setelah dikonsultasikan dengan ahli, dan mendapatkan persetujuan, kemudian peneliti kembali kelapangan, untuk melakukan pengamatan dan menetapkan calon partisipan dengan cara purposive sampling, peneliti melakukan personal kontak dan membina hubungan saling percaya dengan cara memperkenalkan diri dan menjelaskan tujuan dan manfaat penelitian pada partisipan.
Setelah calon partisipan bersedia, peneliti menjelaskan hak-hak dan kewajiban partisipan. Setelah partisipan memahami tujuan penelitian dan setujuh menjadi partisipan, selanjutnya partisipan mengisi informed consent sebagai pernyataan persetujuan partisipan untuk terlibat dalam penelitian yang dilakukan dengan memberikan tanda tangan. Tempat dilangsungkan wawancara semuanya di rumah partisipan dalam kondisi aman tidak bising, dan menjaga privasi partisipan. Pertanyaan yang diajukan berdasarkan pedoman wawancara yang dibuat. Selanjutnya mengajukan berbagai pertanyaan berdasarkan topik yang muncul saat wawancara untuk menggali informasi yang lebih dalam. Setelah selesai melakukan wawancara, buat segera transkrip hasil wawancara. Selanjutnya peneliti melakukan analisis data dari transkrip yang telah dibuat.

Analisa data dengan menggunakan metode Colaizzi (1978) yang terdiri dari 7 langkah sebagai berikut:

1. Membaca dan membaca kembali deskripsi tentang fenomena yang telah diperoleh.

2. Mengekstrasi pernyataan penting yang berkaitan dengan fenomena yang diteliti.

3. Merumuskan makna untuk pernyataan penting untuk menjelaskan makna yang tersembunyi dalam berbagai konteks fenomena.

4. Mengkategorikan makna kedalam kelompok tema dan mengkonfirmasi kosistensi antara temuan yang muncul.

5. Mengitegrasikan temuan kedalam deskripsi lengkap dari fenomena yang diteliti; menjelaskan mencakup pengkodean segmen teks untuk topik, membandingkan topik untuk tema yang konsisten, dan menjebatani tema untuk makna konseptualnya, yang mengarah pada pembuatan prototype model teoritis tentang fenomena yang diteliti.

6. Memvalidasi temuan dengan kembali ke partisipan peneliti untuk menanyakan bagaimana deskripsi universal dibandingkan dengan pengalaman pribadi partisipan.

7. Memasukkan setiap perubahan berdasarkan partisipan kedalam deskripsi akhir dari fenomena tersebut.

\section{HASIL DAN PEMBAHASAN}

Karakteristik partisipan dalam penelitian ini berjumlah 9 orang yang memberikan perawatan pada penderita stroke dirumah di wilayah kota Jambi. Usia partisipan berada pada rentang 23-62 tahun, dengan sebagian besar partisipan berjenis kelamin perempuan $55,6 \%$, pekerjaan IRT atau tidak bekerja 33,3\%, lama merawat pasien satu bulan sampai 6 tahun, pendidikan terakhir SMA sederajat 44,4\%, hubungan dengan pasien sebagai anak kandung 55,6\%, status pernikahan menikah 88,9\%. Tipe keluarga partisipan dalam penelitian ini adalah extended family.

Karakteristik pasien dalam penelitian ini berjumlah 9 orang. Usia pasien berada pada rentang 36-72 tahun, sebagian besar berjenis kelamin perempuan 55,6\%, didapat mayoritas tipe stroke iskemik $77,8 \%$ dengan NIHSS 8-18.

Hasil dari Analisis data di dapat 4 tema dari pengalaman keluarga merawat penderita pasca stroke. 
Tema pertama yaitu: ketergantungan aktifitas seharihari pada keluarga yang mencakup 7 subtema yaitu keterbatasan nutrisi/cairan, keterbatasan pemenuhan kebutuhan eliminasi (BAK/BAB), keterbatasan pemenuhan kebutuhan kebersihan diri, keterbatasan pemenuhan kebutuhan berpakaian dan berhias, keterbatasan pemenuhan kebutuhan mobilisasi, keterbatasan pemenuhan kebutuhan spiritual, dan keterbatasan pemenuhan kebutuhan sosial. Semua partisipan mengungkapkan keterbatasan kebutuhan yang dialami penderita pasca stroke yang dirawat dirumah oleh partisipan. Berikut ini ungkapan yang dinyatakan oleh salah satu partisipan berdasarkan hasil wawancara:

"Dio nggak bisa lagi bergerak, pokoknya kayak ginilah terbaring, kita harus sabar nyuapi dia, mulutnya diakan payah nelannya bu. Kadang kita kasih susu saja sudah keselek, batuknya sampai nak keluar matanya" (P1)

Tema yang kedua adalah upayah yang dilakukan keluarga memenuhi aktifitas perawatan diri, yang terdiri dari 8 subtema yaitu pemenuhan kebutuhan nutrisi, cairan, eliminasi (BAK/BAB), kebersihan diri, berpakaian dan berhias, mobilisasi, spiritual dan interaksi sosial. Partisipan mengungkapakan upaya yang dilakukan untuk memenuhi kebutuhan penderita pasca stroke. Sebagaimana pernyataan yang diungkapkan oleh seorang partisipan dibawah ini:

"Bisa dikatakan lumpuhlah, susah juga, dia nggak bisa mandiri lagi, kek bayilah, dibuka pampersnya, buang pampers yang lama, kito bersihkan dulu dari mukanya, sudah itu dikasih bedak, baru pasang pampers, baru ganti baju sama kainnyo, baru kasih bedak lagi, baru dikasih parfum kayak gitu" (P4)

Tema ketiga adalah kendala yang dihadapi pada pemberi asuhan, yang mencakup 7 subtema yaitu keterbatasan pengetahuan dan keterampilan dalam memberikan perawatan, kesulitan dalam memenuhi ADL pasien, perubahan kondisi fisik, perubahan waktu istirahat dan tidur, perubahan kondisi psikologis, perubahan aktifitas sosial dan perubahan kondisi ekonomi. Hal ini dapat dilihat dari ungkapan yang dinyatakan oleh beberapa partisipan dibawah ini:

"Orang tua pulang kemarin itu, kami harus apa? Bingung? Harus dikasih obat apa? Obat yang mana? Makan, makan apa? Harus digimanai orang tua ngak tahu? Ya inisiatif bu, ini orang tua kembali lagi seperti anak kecil ya kasih dot"(P6)

"Mandinya sekalilah bu, mana telaplah kito (tertawa) ha ha ha. Dibantu suami. Dio berat bu, ngak bisa, lain kayaknya beratnya, karena stroke neh lain buk. Ngak tahulah kayaknyo berat tuh melebihi dia yang normal, apa karena sudah mati sebelah? Tapi serius bu, memang beratnya lain nian" (P1)

"Adolah, paling sakit-sakit inilah, pening, tadinyo ado darah tinggi jugo, kurang tidur, yang iyo capek, jadi kurang tidur,...pakek baju kito, semuanyo kito gitukan, kadang-kadang ngadapi orang sakit nih, sehari dua, tiga hari tuh yo susah, kalau sudah 2 bulan tuh, rasonyo jadi capek, yang bikin marah kito tuh, karena capek,...karna kito mau istirahat, dio manggil kito" (P5)

Selain kesulitan dalam memenuhi kebutuhan ADL pasien, dampak fisik dan psikologis keluarga mengalami perubahan aktifitas sosial, sebagaimana yang diungkapkan oleh beberapa partisipan dibawah ini:

"Kita jadinya ngak bersosial sama tetangga, gitukan yang biasanya kita bisa yach siraturrahmi kerumah keluarga, kerumah tetangga gitu, sekarang ngak bisa habis waktu untuk ngurus dia" (P1)

Keluarga juga mengalami perubahan kondisi ekonomi. Berikut ini pernyataan yang diungkapkan oleh beberapa partisipan:

"Anak-anaklah yang ngasih makan, semuanya kan anak- anak, dak dio, dio tidak bekerja lagi" (P7)

Tema keempat adalah harapan keluarga, Partisipan mengungkapkan harapan pada penderita stroke kondisinya segera membaik dan mampu melakukan aktifitas sebelum terkena stroke, $\mathrm{Hal}$ tersebut diungkapkan oleh beberapa partisipan sebagaimana pernyataan dibawah ini:

"Aku ingin, seperti biaso dio sehat. Seperti biasolah, sehat nian. Berjalan seperti biasa" (P2)

"Dio bisa berdiri, bisa bicara, bisa berjalan, bisa ngobrol dengan tetangga, gitukan bisa sholat" (P9)

\section{Pembahasan}

Berdasarkan hasil analisis data ditemukan tema pertama yaitu ketergantungan aktifitas sehari-hari pada keluarga. Defisit neurologis berupa hemiplegia/hemiparesis, afasia/disatria, disfagia, defisit kognitif dan gangguan keseimbangan yang dialami penderita pasca stroke berdampak pada keterbatasan pemenuhan kebutuhan nutrisi/cairan, eliminasi (BAB/BAK), kebersihan diri, berpakaian dan berhias, mobilisasi, spiritual dan sosial. Keterbatasan yang dialami penderita pasca stroke yang dirawat di rumah oleh partisipan mengakibatkan ketergantungan aktifitas sehari-hari pada keluarga.

Penelitian ini sesuai dengan hasil penelitian (Hesamzadeh et al. (2016) menyatakan defisit neurologis yang terjadi pada pasien stroke mempengaruhi aktifitas perawatan diri dan mobilitas penderita stroke sehingga bergantung pada caregiver. Studi yang lainnya menyebutkan defisit fungsional yang dialami penderita stroke misalnya frustasi dan tidak berdaya berdampak pada ketergantungan ADL pada caregiver (Grant et al., 2004).

Pada tema kedua yaitu upaya yang dilakukan keluarga memenuhi aktifitas perawatan diri. Keluarga dalam menjalankan fungsi keluarga merawat penderita pasca stroke dirumah, keluarga berupaya memenuhi hampir semua kebutuhan penderita pasca stroke karena defisit fungsional yang dialami penderita stroke, upaya yang dilakukan keluarga meliputi pemenuhan kebutuhan nutrisi, cairan, kebersihan diri, berpakaian dan berhias, mobilisasi, spiritual dan sosial. 
Tema upaya yang dilakukan keluarga pada penderita pasca stroke merupakan bentuk dukungan keluarga. Penderita stroke membutuhkan dukungan sosial, emosional, dan finansial yang merupakan faktor penting dalam pemulihan dan untuk meningkatkan kesehatan penderita stroke (Blessing \& Oluwagbemiga, 2017). Sejalan dengan penelitian yang dilakukan oleh Arafat, Ratna, Mustikasari, \& Majid (2018) menyatakan dukungan spiritual yang diberikan keluarga, teman, kerabat, dan tim profesional di rumah sakit memberi energy pada penderita stroke untuk semangat mempertahankan kesejahteraan psikologis dan menjadi motivasi untuk melalui fase pemulihan dengan optimisme.

Tema ketiga yaitu kendala yang dihadapi pada pemberi asuhan. Defisit neurologis sedang sampai berat, yang dialami penderita pasca stroke, mengakibatkan ketergantungan kepada pemberi asuhan, untuk memenuhi hampir semuan ADL penderita pasca stroke. Sementara sebagian besar keluarga adalah orang awan yang baru pertama kali merawat penderita stroke dirumah, yang tidak memiliki pengetahuan cara merawat penderita stroke dirumah dan minimnya informasi yang didapatkan keluarga, sehingga keluarga mengungkapkan keterbatasan pengetahuan dan keterampilan dalam merawat penderita pasca stroke. Selain itu keluarga mengalami kesulitan dalam memenuhi kebutuhan ADL pasien, keluarga mengalami perubahan kondisi fisik, perubahan waktu istirahat dan tidur, perubahan kondisi psikologis, perubahan aktifitas sosial dan perubahan ekonomi.

Beberapa penelitian telah mengidentifikasi keluarga sebagai caregiver juga kurang memiliki keterampilan dalam merawat anggota keluarga yang menderita stroke, karena itu membutuhkan edukasi dan informasi (Daulay et al., 2014). Informasi yang dibutuhkan Keluarga meliputi informasi pengobatan atau rehabilitasi dan bagaimana menangani keadaan darurat medis pasien stroke (Tsai, Yip, Tai, \& Lou, 2015). Keluarga sebagai caregiver juga mengalami kesulitan dalam memenuhi ADL pasien disebabkan defisit fungsional yang dialami penderita stroke, sehingga berdampak ketergantungan ADL pada caregiver, caregiver merasa kewalaham, frustasi, tak berdaya dan tidak mampu mengelolah pekerjaan, rumah tangga dan tanggung jawab pengasuhan (Grant et al., 2004). Keluarga dalam menjalankan perannya banyak memiliki keterbatasan fisik dan finansial, selain itu tugas pengasuhan yang selama bertahun-tahun merawat penderita stroke berdampak negatif pada sosial keluarga sebagai caregiver (Daulay et al., 2014).

Keluarga sebagai caregiver mengalami masalah psikologis berupa kecemasan /kegelisahan, depresi disebabkan tugas merawat penderita stroke (Ganapathy et al., 2015). Masalah psikologis yang dialami keluarga karena koping keluarga disfungsional yang dapat menimbulkan stress yang berdampak pada kesehatan fisik (McCubbin, 1979). Merawat penderita stroke juga berdampak pada perubahan ekonomi yang dialami keluarga di sebabkan karena beban keuangan yang besar, diakibatkan biaya langsung untuk pengobatan penderita stroke, biaya perawatan, kunjungan kedokter/rumah sakit dan kehilangan produktivitas (Gbiri et al., 2015).
Tema keempat yaitu harapan keluarga, stroke adalah kondisi dimana terjadinya defisit neurologis yang berdampak pada defisit fungsional. Harapan keluarga pada penderita stroke agar segera membaik adalah hal positif sebagai motivasi karena penyembuhan stroke merupakan proses panjang yang membutuhkan banyak waktu, usaha, serta kesabaran.

Hasil penelitian ini sejalan dengan penelitian yang dilakukan Lutz, Young, Cox, Martz, \& Creasy (2011) menemukan harapan keluarga pada penderita stroke agar segera membaik, dalam hal ini kembali pada kegiatan sebelum terkena stroke. Julianti (2015) dalam penelitiannya menemukan harapan keluarga berkaitan dengan fungsi, sumber dan bentuk dukungan, caregiver berharap kesehatan bagi diri caregiver, kesembuhan bagi anggota yang dirawat dan keluarga berharap adanya bantuan pemerintah terkait beban biaya yang sangat besar merawat pasien pasca stroke di rumah.

\section{SIMPULAN}

Minimnya informasi yang didapatkan keluarga dan sebagian besar keluarga adalah orang awan yang baru pertama kali merawat penderita stroke dirumah sehingga kurang memiliki pengetahuan cara merawat penderita stroke dirumah, keluarga juga mengalami kesulitan dalam memenuhi kebutuhan ADL pasien, keluarga mengalami perubahan kondisi fisik, perubahan waktu istirahat dan tidur, perubahan kondisi psikologis, perubahan aktifitas sosial dan perubahan ekonomi. Berdasarkan hasil penelitian disarankan keluarga perlu mendapatkan edukasi dari dokter, perawat dan anggota tim stroke dimulai sejak pasien masuk rumah sakit dan dievaluasi kembali pada saat pasien akan pulang mengenai pengetahuan dan keterampilan merawat penderita pasca stroke dirumah.

\section{DAFTAR PUSTAKA}

Arafat, R., Ratna, S., Mustikasari, \& Majid, A. (2018). Spiritual Coping in People Living with Stroke. International Journal of Caring Sciences, 11(2), 658-662. Retrieved from http://search.ebscohost.com/login.aspx?direct=tru e\&db=ccm\&AN $=131851604 \&$ site $=$ ehost-live

Blessing, M., \& Oluwagbemiga, O. (2017). Effectiveness of Social Support in Coping with Stroke by Medically III Patient in Ibadan. International Journal of Neurorehabilitation, 04(04). https://doi.org/10.4172/2376-0281.1000281

Colaizzi, P. F. (1978). Psychological research as the phenomenologist views it. In R. Valle \& M. King (Eds.), Existential phenomenological alternatives for psychology. New York: NY: Oxford University Press.

Daulay, N. M., Setiawan, \& Sitepu, N. F. (2014). Pengalaman Keluarga sebagai Caregiver dalam Merawat Pasien Strok di Rumah. Jurnal Keperawatan Padjadjaran, 2(3), 161-170. https://doi.org/Email : nanda_daulay88@yahoo.com

Friedman, M. M., Bowden, V. R., \& Jones, E. G. (2010). Buku Ajar Keperawatan Keluarga: riset, teori, \& praktik. (E. Tiar, Ed.) (5th ed.). Jakarta: EGC.

Ganapathy, V., Graham, G. D., Dibonaventura, M. D., Gillard, P. J., Goren, A., \& Zorowitz, R. D. (2015). 
Caregiver burden, productivity loss, and indirect costs associated with caring for patients with poststroke spasticity. Clinical Interventions in Aging, 10 , 1793-1802. https://doi.org/10.2147/CIA.S91123

Gbiri, C. A., Olawale, O. A., \& Isaac, S. O. (2015). Stroke management: Informal caregivers' burdens and strians of caring for stroke survivors. Annals of Physical and Rehabilitation Medicine, 58(2), 98103. https://doi.org/10.1016/j.rehab.2014.09.017

Grant, J. S., Glandon, G. L., Elliott, T. R., Newman, J., Weaver, G., \& Michael. (2004). Caregiving problems and feelings experienced by family caregivers of stroke survivors the first month after discharge. International Journal of Rehabilitation Research, Vol 27 No. Retrieved from doi: 10.1097/01.mrr.0000127639.47494.e3

Hesamzadeh, A., Dalvandi, A., Bagher Maddah, S., Fallahi Khoshknab, M., Ahmadi, F., \& Mosavi Arfa, N. (2016). Family caregivers' experience of activities of daily living handling in older adult with stroke: a qualitative research in the Iranian context. Scandinavian Journal of Caring Sciences, 31(3), 1-12. https://doi.org/10.1111/scs.12365

Johnson, W., Onuma, O., Owolabi, M., \& Sachdev, S. (2016). Stroke: a global response is needed. Switzerland: Bulletin of the World Health Organization.

https://doi.org/http://dx.doi.org/10.2471/BLT.16.18 1636

Julianti, E. (2015). Pengalaman Caregiver Dalam Merawat Pasien Pasca Stroke di Rumah pada Wilayah Kerja Puskesmas Benda Baru Kota Tangerang Selatan. Jurnal Universitas Islam Negeri Syarif Hidayatullah Jakarta. Retrieved from http://repository.uinjkt.ac.id

Kemenkes RI. (2017). Program Indonesia Sehat dengan pendekatan keluarga. Retrieved January 27, 2019, from

http://www.depkes.go.id/article/view/17070700004 /program-indonesia-sehat-dengan-pendekatankeluarga.html

Kemenkes RI Ditjen Yankes. (2018, May 9). Perawatan pasien pasca stroke di rumah. Ditjen Yankes. Retrieved from http://www.yankes.kemkes.go.id/read-perawatanpasien-pasca-stroke-di-rumah-4143.html

Lutz, B. J., Young, M. E., Cox, K. J., Martz, C., \& Creasy, K. R. (2011). The Crisis of Stroke: Experience of Patients and Their Family Caregivers. Top Stroke Rehabilitation, 18(6), 1-16. https://doi.org/10.1310/tsr1806-786.The

McCubbin, H. (1979). Integrating coping behavior ill family stress theory. Journal of Marriage and the Family, 41, 23-241.

Smeltzer, S. C., Hinkle, J. L., Bare, B. G., \& Cheever, K. H. (2009). Brunner \& Suddarth's Textbook of Medical-Surgical Nursing (12th ed.). Lipincott Williams \& Wilkins.

Taştekin, N. (2015). Rehabilitation and Quality of Life in Stroke Patients. Physical Medicine and Rehabilitation, 61, 97-98.

Tsai, P. C., Yip, P. K., Tai, J. J., \& Lou, M. F. (2015). Needs of family caregivers of stroke patients: A longitudinal study of caregivers' perspectives. Patient Preference and Adherence, 9, 449-457. https://doi.org/10.2147/PPA.S77713

Venketasubramanian, N., Yoon, B. W., Pandian, J., \& Navarro, J. C. (2017). Stroke Epidemiology in South, East, and South-East Asia: A Review. Journal of Stroke, 19(3), 286-294. https://doi.org/10.5853/jos.2017.00234

WHO. (2018). Stroke, Cerebrovascular accident. Retrieved May 24, 2018, from https://www.who.int/topics/cerebrovascular_accide nt/en/

WHO. (2018). The top 10 causes of death. Retrieved May 24, 2018, from https://www.who.int/news$\mathrm{room} /$ fact-sheets/detail/the-top-10-causes-of-death 